\title{
CEOs must seek pharmaceutical partners now
}

Oh, for the good old days!

Time was when being a biotech chief executive officer (CEO) was an enviable position. To marshall cutting-edge science in search of cures for human misery. To dream of Nobel laureates wandering the halls engaged in stratospheric discourse. These were the expectations of the 1980s biotech manager, who can now be forgiven for having viewed these expectations as reasonable, just rewards. Those were the days, you will remember, when having a patent seemed tantamount to having an approved product, one that virtually guaranteed sales in the hundreds of millions of dollars. Remember? After all, if we could clone the gene, it couldn't be all that hard to manage the product through clinical trials.

We can be forgiven if, in these dismally realistic days, we choose to forget how easy it all seemed. In those gentle, innocent times, a manager could stand before a group of investors and promise, with a straight face, to transform six scientists with a patent into a fully integrated pharmaceutical company (FIPCO). In those times, a CEO could project six years of $\$ 20$ million annual burn rates, explain the razzle-dazzle science with engaging slides, and expect to fund much of that burn rate with equity capital from investors eager to own part of "the next Amgen (Thousand Oaks, CA)."

These days are not those days. Today, a CEO can announce successful completion of phase II studies, and investors and analysts will yawn. Today, merely beginning phase III trials can be viewed as sufficient rationale for selling stock short. We have gone from expectations of companies being FIPCOs, through dreams of companies being FIDCOs, or fully integrated development companies, to times when being a "virtual company" may itself seem too ambitious. Today, to call capital scarce is to demonstrate a commanding grasp of the obvious. Today, to be a biotechnology executive is to warrant treatment with serotonin-reuptake inhibitors-including Eli Lilly's (Indianapolis, IN) Prozac or Pfizer's (New York) Zoloft-and to require the courage of an Army Ranger.

And yet. . .

Biotechnology companies are continuing to build value, perhaps more quietly than in the past, but with no less celerity. They are marshalling product candidates through preclinical development and clinical trials, while defining new scientific tools and techniques, even as they sharpen familiar ones. Many companies have even been smart enough to learn the hard lessons taught by the errors of some of their unfortunate predecessors. An inescapable lesson of the last five years in biotechnology is that drug development is a challenging process, one requiring time and capital. It is possible for companies to get lucky, but that hardly constitutes an enviable strategy.

It is a challenging time-rather than an impossible time - for biotechnology executives. Called on to do more with less, astute managers are recognizing the structural limitations imposed by the nature of biotechnology products, the need for more comprehensive and careful clinical development, and the intense competition for capital. Management has always been an important part of the recipe for a successful company. Today, it has become a central, indispensble ingredient. What should the biotech CEO be doing today? In our view, the central imperative is to align the company for the long term.

Management must cast a critical eye at the technology base of its company, at the stage of development of its technology, and at the probability of success of its product portfolio. And then it must pursue the right relationships to maximize that probability. Hoping anxiously for the "window" to open is a wonderful and clarifying avocation. Planning for success in the expectation that the window will remain nailed shut is a necessary feature of responsible biotech leadership. The single most dangerous temptation for today's biotech executive is to focus so intently on preserving product marketing rights that opportunities for favorable partnering lapse.

Moreover, the pharmaceutical companies have come alive. We have begun to see some major collaborations and acquisitions, and we fully expect to see some more. The combination of Chiron (Emeryville, CA) and Ciba-Geigy (Basel) creates a business-development juggernaut that will play a powerful role in consolidating technologies. Fraternal alliances between biotechnology companies, on the other hand, may provide some technology diversification, but these alliances provide relatively little liquidity or capital.

The capital supply of pharmaceutical partners is not limitless. They are uniformly focused on investing in relationships that further theirstrategic positions, and they will gladly pay for what they need. But every external relationship competes for resources with the internal programs of pharmaceutical companies, and program valuation or product valuation by biotech companies is as important in the pharmaceutical-relationship market as in the capital markets. It is true that strategic buyers will often value biotech-company programs more generously than institutional investors. Nevertheless, for the biotech company to hold out for a valuation that cannot realistically be realized in the absence of significant investment jeopardizes the possibility of completing a transaction.

The time to align is now. The competition for capital-and the need to maintain the pace of product development as patent lives tick down-argue for the diligent pursuit of the best partnerships. Today's biotechnology executive must be a master of structuring, executing, and managing such partnerships, and he must be equipped with an internal navigation system to balance valuation desires with market reality. The reward for such leadership, however, will be the sustained development of leading-edge products that will provide healthy returns for the invested capital and time

Gregory Brown is vice president of Vector Securities International (Deerfield, IL).

Peter Drake is cofounder and executive vice president of Vector Securities International.
CEOs must be

masters of

structuring and

managing

partnerships.

And they must

balance

valuation

desires with

market reality. 